\title{
AWARENESS, ACCESSIBILITY AND ABILITY TO USE COMPUTERS BY PRIMARY SCHOOL PUPILS
}

\author{
Dr. Thadei Kiwango \\ Lecturer, Department of Informatics, Institute of Accountancy Arusha, United Republic of Tanzania
}

Article DOI: $\underline{\text { https://doi.org/10.36713/epra2773 }}$

\begin{abstract}
This paper is a determination of use of digital technology for instructional purposes in out of school environment. The paper specifically explores the awareness of primary school pupils on the significance of using computers, access to computers and the ability to use computers. A total of 458 pupils were selected from 9 primary schools in three (3) divisions of Meru District in Arusha Region. The findings of the study shows that only 18.8\% of pupils were aware of the usefulness of computers, while even smaller percentage of pupils (9.6\%) had computers at home. On the other hand, only $16.6 \%$ of pupils could use computers. On the basis of the findings, it could be inferred that although some pupils are aware that computers can potentially facilitate learning, they are not adequately available at home, while also quite few pupils can use them. On the basis of these observations; the government, school administrators and other stakeholders in education should work together to raise pupils' awareness of the usefulness of computers, along with making computers available and enabling pupils to make use of them to improve learning both in regular classroom and out of school time. At the bottom line, studies that are geared towards exploring the robust approaches which not only can raise pupils' awareness but can more importantly make families see the importance of availing computers to their school children while at the same time encouraging pupils to use computers to improve their learning at school and out of school time are inevitable.
\end{abstract}

\section{INTRODUCTION}

The Government of Tanzania has made several efforts to foster the use of educational technology with a view to improving the teaching and learning process. This is manifested not only in the Tanzania Vision 2025 (URT, 1999), but also in relevant policies such as the ICT Policy for Basic Education (URT, 2014) and the National ICT Policy of 2016 (URT, 2016). The National ICT Policy of 2016, for example, is intended to ensure public awareness of the significance of Information technology in improving the living standards of the local population. Additionally, the
Policy calls for the need to ensure accessibility to technology-based products and using the same to combat poverty, ignorance and diseases. Similarly, the Information and Communication Technology for Basic Education Policy is partly a response to the observed lack of awareness on the use of ICT; thus the Government intends to bridge this gap. As for the Tanzania Vision, it encourages investment in the improvement of citizen's skills and ability to use ICT as a necessary requirement for exploiting technology with the ultimate goal of improving living. However, despite improving education through technology, 
policies and other initiatives; awareness, availability and use of educational technology may not produce the expected outcomes, unless efforts are also expedited to ensure involvement of various stakeholders particularly learners, teachers, parents, schools and the Government.

The best approach to improving investment in educational technology is to acknowledge its worth in shaping teaching and learning. According to Costley (2014), technology enhances learning by making pupils actively engaged, while also facilitating retention of more information. Technology also facilitates collaboration among learners to learn from one another, enables learning from real experiences and consequently improves performance. (DePasquale, McNamara, and Murphy, 2003). Lin and Yang (2011) find that wiki technology enables pupils to receive prompt feedback from instructors, consequently improving their writing skills as opposed to traditional learning styles. A study by Herron (2010) determined the role of technology in improving pupils' interest in Mathematics. The study found that technology provides many instructional activities from which learners can select materials relevant to their levels without much difficulty. The merits of technology in education are also acknowledged by Hollnagel (2013) who establishes that technology improves the level of comfort, task-technology fit and learners' satisfaction. Therefore, primary school pupils need to be enabled to use technology at early ages so that they can see the merits of technology and embrace it to better their learning

It is worth understanding that the advantages of using technology in learning cannot be exploited, unless efforts are made to ensure awareness, availability and its actual use among learners especially in the current technology-driven $21^{\text {st }}$ century. While this holds true for Tanzania, Maro (2104) noted that schools had acute shortage of technological devices notably computers. For example, the Author found only 7,035 computers in about 180,987 secondary schools in Tanzania, whereas $37.3 \%$ of them were meant for administrative issues. With regard to relationship between awareness and academic achievement, on the other hand, Magre (2011) supports that there is significance difference between the level of awareness on information technology and academic achievement in secondary school students.

If awareness and use of technology is limited among secondary school students, one could imagine the situation in primary school. Nihuka and Peter (2014) find out the use of computer among primary school pupils with a focus on their ability to use the device. The findings showed that only a small proportion of pupils (11.4\%) could make use of basic simple computer applications. Nevertheless, many of studies with respect to application of educational technology placed their focus on school environment and overlook home environment. It is important to realize that learning during school time and after school hours supports each other (Metlife Foundation, 2012) and are all important in bringing about transformation in education system. This is the basis of this study to address this situation by examining awareness, availability and use of computers at home among primary school pupils. This is important since it will inform policy makers and educational stakeholders at large to make informed decisions with respect to the investment and applications of information technologies in primary schools.

\section{LITERATURE REVIEW ICT Index}

ICT index analyzes and evaluates the development and potential of Information and Communication Technology (ICT) based on pertinent indicators of diffusion across nations of the world (UNCTAD 2003). Some ICT index reports use slightly different indicators depending on the aims of the report in question. The International Telecommunication Union (ITU), for instance, applies three key indicators, namely ICT access, with a focus on fixed-telephone lines per 100 inhabitants, International Internet bandwidth (bit/s) per Internet user, Mobile-cellular telephone subscriptions per 100 inhabitants, percentage of households with computer and percentage of households with Internet access. The second index is ICT use, which comprises the percentage of individuals using the Internet, fixed (wired)-broadband Internet subscriptions per 100 inhabitants and Active mobilebroadband subscriptions per 100 inhabitants. The last index is ICT skills, which subsumes adult literacy rate, secondary gross enrolment ratio and tertiary gross enrolment ratio. On the other hand, indicators for the United Nations Conference on Trade and Development, include connectivity-internet hosts, telephone mainlines and mobile subscribers. Another indicator is accessinternet users, average revenue and call costs. Policy environment is another indicator, which is realized by competition, long distance and internet exchange. The other indicator is usage-incoming and outgoing telecommunication traffic.

Other organizations and institutions such as the UN ICT Task force and UNESCO also use varied indicators. The guideline adopted by the UN ICT Task force (2005) falls into two main categories, which are household and business indicators. On the one hand, Household indicators subsume household electricity 
connectivity, ownership of radio, fixed telephone line, mobile phone, TV, access to computer and the internet and methods of access. Other considerations are location, frequency and purpose of Internet use. Other indicators include types and vale of products and services purchased over the Internet. On the other hand, business indicators comprise most of the household indicators; and extend to local network, corporate website, recent ICT investments, sharing of computer ant the internet among employees, purpose for using the Internet, value of Internet purchase and ICT training arrangements.

The UNESCO (2009) approach in measuring ICT development consists of three stages; which are ICT readiness, ICT intensity and ICT impacts. ICT readiness pertains to the status of ICT infrastructures and their accessibilities whereby the degree of ereadiness determined by the degree of ICT adoption and dynamics which influence the capacity for countries to harness the opportunities availed by ICT. The dynamics could be socio-economic, political, regulatory and market-oriented, among others. According to Adam (2010), the UNESCO methodology is relevant in that it focuses on the level of development of infrastructure and relevant policies as a measure of ICT readiness. Relevant to this work, the World Economic Forum (2011) is of the view that it is not enough to view the level of e-readiness as the degree of technology integration and national policies; it is essentially the capacity of businesses, individuals and the community to sufficiently harness the potentials of ICT to bring positively impact on their livelihood. Awareness is implicit in ICT readiness since it enhances the human competence towards embracing technology in its multifaceted manifestations.

The intensity of ICT has to do with the degree of the use of ICT in daily life. Bjarne (2013) notes that use of technology is manifested in economic use, and it include businesses, e-commerce and market competition. Other uses of the kind are export trade and foreign investment, among other factors. Another manifestation is government use; and this subsumes policy making, privacy, intellectual property, trade, regulations, electronic signatures e-government, political openness and democracy. The use of technology is also manifested in such circles as educational and social use. With regard to use in education, it involves use in schools, availability of trained workforce and training in technology). As for social use, it is about use in every day's life by the public to address inequality and basic literacy. ICT impact is all about the results of societal use of ICT. For instance, according to UNESCO (2009), the impact of ICT in education system is the determination of the transformations enabled by use of ICT in terms of performance such as improving teaching and learning, improving learners' performance, creating new skills in the labour market, creating lifelong learning opportunities and enhancing management of educational institutions and facilities. For the purpose of this work, the indicators applied by the United Nations ICT Task force and UNESCO are adopted since they reflect on levels of availability and use in gauging the development of ICT.

\section{METHODOLOGY}

In this research work, a case study design was adopted drawing subjects from Meru District in Arusha Region. Arusha is among the largest urban centres in Tanzania whose population was thus thought to have well established technological infrastructure (Lamudi, 2015; TCRA, 2013). This qualification presumably gives the population better positioned to use technology for various uses. Meru District as a peri-urban district was also considered to have relevant socio-cultural and economic features which represent the majority of Tanzanians as opposed to typical rural and urban sites.

With primary schools constituting the focal point of this research work, a list of all primary day primary schools was obtained from three Divisions of the District, with the assistance of the District Chief School Quality Assurance Officers. The latest NECTA examination results used to sort the schools in each Division according to their performance where it was splinted into three groups of higher, moderate and low performers. Then one school was selected from each group (one from the top, a second from the mid and the third from the bottom of each list) making a total of three schools in each Division and a sum of nine schools for the three Divisions. This was intended to have a balanced selection of schools to represent geographical and educational settings. As the study was intended to deal with home environment, day primary scholars were the target. The preference of primary school pupils was prompted by the need to cultivate positive attitude of the use of educational technology from early ages with a view to encouraging them to embrace educational technology in the future more productively.

Class seven pupils from each school were asked to participate on the study on the basis of their availability and their willingness to volunteer. They were preferred on the assumption that they are more mature and thus more exposed to technology devices though not necessarily for educational ends. Additionally, they could understand research questions better than lower classes. There were 458 participants from class seven who responded to the structured 


\section{EPRA International Journal of Research and Development (IJRD) \\ Volume: 5 | Issue: 5 | May 2020 \\ - Peer Reviewed Journal}

questionnaire, which demanded them to indicate their level of awareness of the usefulness of computer, if their families owned computers, and if they independently used computers without assistance. Computer is selected as one of the leading and multipurpose digital tool that can be used for learning. For instance, learners can use a computer to access internet, create files, communicate, store and retrieve files, and son. The results were tabularized and with the assistance of SPSS the descriptive statistics were applied to analyze the same.

\section{FINDINGS}

The findings correspond with the three areas of concern, with particular focus on the awareness of usefulness of computers, availability of computers and the ability of primary school pupils to use computers.

\section{Awareness of pupils on usefulness of computers}

With regard to the above, pupils were required to show their awareness pertaining to usefulness of computers. The findings are summarized in Table 1.

Table 1: Awareness of pupils on usefulness of computers

\begin{tabular}{|ll|c|c|c|}
\hline Theme & Response & Frequency & Percent \\
\hline Awareness & of & Yes & 372 & 18.8 \\
\cline { 3 - 5 } usefulness & of & No & 86 & 81.2 \\
\cline { 2 - 4 } computers & Total & 458 & 100 \\
\hline
\end{tabular}

Source: Field data (2018)

The findings as summarized in Table 1 above indicate that $81.2 \%$ of primary school pupils were not informed of the usefulness of computers; and that significantly small proportion $(18.8 \%)$ had the understanding regarding the usefulness of computers. This is an indication that most of the pupils had not realized the significance of computers; meaning also that they did not know that computers could improve their learning. The lack of understanding could be attributed to limited exposure to computer both in school and out of school especially home. This suggests implicitly that most primary schools in the country may not have computers; or else they have limited applications of computers.

\section{Availability of computers at home}

Pupils were also asked to state whether they had access to computers at home. The findings are presented in Table 2 below.

Table 2: Availability of computers at home

\begin{tabular}{|l|c|c|c|}
\hline Theme & Response & Frequency & Percent \\
\hline $\begin{array}{l}\text { Availability } \\
\text { computers }\end{array}$ & Yes & 44 & 9.6 \\
\cline { 2 - 4 } & No & 414 & 90.4 \\
\cline { 2 - 4 } & Total & 458 & 100 \\
\hline
\end{tabular}

Source: Field data (2018)

As seen in Table 2 above, a significant proportion of pupils $(90.4 \%)$ indicated that their families did not own computers, while only $9.6 \%$ of them acknowledged their families to have computers. This suggests that the pupils whose families had computers were more likely to access and use them for different purposes, not necessarily academic. Conversely, most of pupils were likely to have very limited access to computers out of home since the devices were not found at home. These findings seem to corroborate the observation regarding awareness of the usefulness of computers as reported earlier (see Table 1). To some extent, the situation could be attributed to economic factors and pertinent infrastructures like electricity connectivity.

\section{Ability of pupils to use computers \\ It was also the mission of this research work to determine the ability of pupils to use computers in the absence of support from other individuals. The findings appear in Table 3 below.}


Table 3: Ability of pupils to use computers

\begin{tabular}{|c|c|c|c|}
\hline \multirow{2}{*}{$\begin{array}{c}\text { Ability to use } \\
\text { computers }\end{array}$} & Yes & 76 & 16.6 \\
\cline { 2 - 4 } & No & 382 & 83.4 \\
\cline { 2 - 4 } & Total & 458 & 100 \\
\hline
\end{tabular}

Source: Field data (2018)

As per the findings presented above, $83.4 \%$ of the pupils could not confidently use computer without some assistance. However, the rest of them (16.6\%) indicated that they had the ability to use computer without support. The findings unquestionably mean that most primary school pupils cannot use computers for either academic or other ends. This could be said to be a combined effect of limited access and awareness of usefulness of computers. Economic reasons and lack of supportive infrastructures like electricity may have also contributed to the situation.

\section{DISCUSSION}

This research paper has found that most primary school pupils are unaware of the usefulness of computers. Additionally, pupils have quite limited access to computers since most homes do not own computers. In the same veins, in addition to unawares and limited access, pupils also lack the ability to use computers. This is in line with (Lowther et al., 2012), who found that although computers are useful in educational contexts, there is still limited use of technology in education systems, attributing the situation to limited awareness, and their availability. What is encouraging is that the situation improves as one progress to higher levels of education; for example, Magre (2011) established that $62 \%$ of students in secondary schools understood the usefulness of computers. This could mean that the understanding of usefulness of computers could be increasing as one goes up the education ladder while the opposite is true. As regards availability, Maro (2014) found that availability of computers in primary schools is not encouraging. For example, the study found 7035 computers shared among 180987 primary schools in the country. Moreover, $37.3 \%$ of the available computers were for administrative matters. As for ability to use computers, Nihuka and Peter (2014) observed that only some $11.4 \%$ of primary school pupils could use simple computer applications.

However, studies have shown that learners have more access and use of other technologies such as television. For example, Magoma (2011) concludes that most children in Tanzania can operate television. This agrees with Kiwango (2018), who reports that $83 \%$ of pupils in primary schools could operate television without assistance. These observations mean that availability and ability to use television could be higher than it is the case with computers. Nevertheless, studies have established that majority of children who use the television do so for non-academic pursuits (UNICEF, 2011). Among other factors, the misuse of television and probably other technologies by primary school pupils may be triggered by lack of awareness of its educational use.

\section{CONCLUSION AND RECOMMENDATIONS}

It is concluded in this research paper that the ability to use computers among primary schools in Tanzania is still low partly owing to limited awareness and accessibility. Fortunately, literature shows that majority of pupils in Tanzania have access to television and can use it, although it has also been found that they use television for purposes other than educational. It could be said that if efforts are made especially by parents at home, children could also raise their levels of awareness, availability and use of computers, the same way they have raised levels of access and use of television.

With reference to the findings of this research paper, it is suggested that parents, schools, the government and other stakeholders in education should work together to sensitize and raise awareness, availability and use of technological devices, particularly computers among pupils in order to improve their academic performance. More importantly, given the closure of educational institutions, including primary schools due to the COVID-19 pandemic, some institutions have successfully resorted to out-of-school time (OST) online learning more than ever before. This demands that learners need access to technological devices especially computers and supporting infrastructure. Accordingly, more research is needed to unveil ideal models in the quest to raise awareness, availability and use of educational technology particularly computers at school and home in order to both improve academic performance and deal with challenges that limit the use of traditional classrooms like those posed by COVID19 in the future. 


\section{SJIF Impact Factor: 7.001| ISI I.F.Value:1.241| Journal DOI: 10.36713/epra2016 ISSN: 2455-7838(Online) EPRA International Journal of Research and Development (IJRD)}

\section{REFERENCES}

1. Adam, B. et al (2010). ICT for Development: sustainable technology -supported participatory development for poverty alleviation in the context of digital divides, Bonn university. Retrieved from http://www.zef.de/fileadmin/downloads/forum/docp rog/Termpapers/2010_1_Blake_

Quiros.pdf.

2. Blurton, C. (2002). New Directions of ICT-Use in Education. Retrieved from http://www.unesco.org/education/educprog/lwf/dl/e dict.pdf; accessed.

3. Bjarne, R. et al (2013), Measuring ICT usage quality for information society building, http://pure.au.dk/portal/files/68568192/Measuring ICT_usage_quality_for_information_society_buildi ng_IN_PRESS_GIQ_2014.pdf.

4. Costley, K. C. (2014). The Positive Effects of Technology on Teaching and Student Learning. Retrieved from https://eric.ed.gov/?id=ED554557.

5. Gutnick, A.L., M. Robb, L. Takeuchi, \& J. Kotler. (2011). Always Connected: The New Digital Media Habits of Young Children. New York: The Joan Ganz Cooney Center at Sesame Work-shop. Retrieved from www.ictliteracy.info/rf.pdf/jgcc_alwaysconnected.p df

6. Herron, J. (2010). Implementation of technology in an elementary mathematics lesson: The experiences of pre-service teachers at one university. SRATE Journal, 19(1)

7. Hollnagel Gustav (2013). The Benefits and Limitations of Using Online Technology in Education: Students' and Instructors' Perceptions on Usefulness and Task-technology-fit. Retrieved from

https://www.researchgate.net/publication/29936778 7 _The_Benefits_and_

8. Limitations_of_Using_Online_Technology_in_Edu cation_Students'_and_Instructors'_Perceptions_on _Usefulness_and_Task-technology-

fit/link/56f25dc508ae1cb29a3fo19d/download.

9. Jan-Åke, T. (2002). A case research design for studying contemporary business networks and their development in a changing world, Henriksigatan, Finland

10. Jermaine, S. (2009). The use of Information and Communication Technology in Classroom as a Tool to promote Language among Non-native Preservice English Teachers, University of León.

11. Kiwango, T. (2018). A model to hasten technology integration for out-of-school time learning (Doctoral thesis). Tanzania: University of Dodoma.

12. Lamudi, A. (2015). Which Areas Have The Best Internet Connection In Tanzania? Retrieved from https://www.lamudi.co.tz/journal/which-areashave-the-best-internet-connection-in Tanzania.
13. Lin, W., \& Yang, S. (2011). Exploring students' perceptions of integrating Wiki technology and peer feedback into English writing courses. English Teaching: Practice and Critique,10(2), 88-103

14. Lowther, D. L., Inan, F. A., Ross, S. M., \& Strahl, J. D. (2012). Do one-to-one initiatives bridge the way to 21 st century knowledge and skills?. Journal of Educational Computing Research, 46(1), 1-30

15. Leu, D. J., O’Byrne, W. I., Zawlinski, L., McVerry, G., \& Everett-Cacopardo, H. (2009). Expanding the new literacies conversation. Educational Researcher, 38(4), 264-269.

16. Maro, N. (2014). The Use of Computers in Public and Private Primary Schools in Tanzania: A Digital Divide. International Journal of Computer Applications (0975 - 8887), 103(15).

17. Magre Sunita (2011). International Interdisciplinary Research Journal, Volume-I, Issue-II, Nov-Dec2011

18. Magoma, J. (2011). "The Effects of Electronic Media on Children's Self/Private Reading

19. Behavior, A case of Morogoro Municipality and Mvomero District Tanzania". Retrieved from [https://www.

suaire.suanet.ac.tz:8080/.../jackson, \%20magoma

20. TCRA (2013). "Assessment Report on Migration from Analogue to Digital Broadcasting and Analogue Switch-off Processes in Tanzania. Retrieved from http://www.tcra.go.tz/index.php/publication-andstatistics/reports.

21. UNCTAD. (2003). Information and communication technology development. World Summit on Information Society, 3(2), 1-5.

22. URT. (2016), National Informational and Communication Technology Policy 2016. Retrieved from http://www.mwtc.go.tz/uploads/publications/en1490 101734-National\%20ICT\%20Policy\%202016.pdf.

23. URT (2014). ICT Policy for Basic Education. Retrieved from moe.go.tz.

24. UN ICT Task Force (2005). Global Forum on Harnessing the Potential of ICTs in Education. Dublin, Ireland.

25. UNESCO (2009). Guide to Measure ICT in education. Retrieved from http://www.uis.unesco.org/Library/Documents/ICT _Guide_EN_v19_reprintwc.pdf.

26. UNESCO (2002). nformation and communication technologies in teacher education: A planning guide. Retrieved from http://www.unescobkk.org/fileadmin/user_upload/ic t/ebooks/

27. World Economic Forum(2011). Measuring ICT usage quality for information society building. Retried from http://pure.au.dk /portal/files/68568192/Measuring_ICT_usage_qual ity_for_information_society_building_IN_PRESS_ GIQ_2014.pdf. 